\title{
NF-kB as a Critical Link Between Inflammation and Cancer
}

\author{
Michael Karin \\ Laboratory of Gene Regulation and Signal Transduction, Department of Pharmacology and Pathology, \\ Moores Cancer Canter, UCSD School of Medicine, La Jolla, California 92093-0723 \\ Correspondence: mkarin@ucsd.edu
}

NF-кB transcription factors have been suspected to be involved in cancer development since their discovery because of their kinship with the v-Rel oncogene product. Subsequent work led to identification of oncogenic mutations that result in NF-кB activation in lymphoid malignancies, but most of these mutations affect upstream components of $N F-\kappa B$ signaling pathways, rather than NF- $\mathrm{B}$ family members themselves. NF- $\kappa$ B activation has also been observed in many solid tumors, but so far no oncogenic mutations responsible for NF- $\mathrm{kB}$ activation in carcinomas have been identified. In such cancers, NF- $\kappa$ B activation is a result of underlying inflammation or the consequence of formation of an inflammatory microenvironment during malignant progression. Most importantly, through its ability to up-regulate the expression of tumor promoting cytokines, such as IL-6 or TNF- $\alpha$, and survival genes, such as $\mathrm{Bcl}-\mathrm{X}_{\mathrm{L}}, \mathrm{NF}-\mathrm{kB}$ provides a critical link between inflammation and cancer.

\begin{abstract}
$A$ important chapter in the long saga of ANF-KB is the one dealing with its role as a pivotal link between inflammation and cancer. A possible association between NF- $\mathrm{KB}$ and cancer has emerged during the early days of RelA/p65 cloning and sequencing, which instantaneously revealed its kinship to c-Rel and its oncogenic derivative v-Rel (Gilmore 2003). However, oncogenic mutations that endow RelA, c-Rel, or other NF- $\kappa$ B proteins with transforming activity were found to be rare and mainly limited to lymphoid malignancies (Gilmore 2003). Yet, not only lymphoid cancers, but most solid tumors as well, exhibit activated NF- $\mathrm{KB}$ (Karin et al. 2002). As in most of these cases, no loss-of-function ІкB
\end{abstract}

mutations or gain-of-function IKK mutations have been detected. We have suggested that NF- $\kappa \mathrm{B}$ activation in cancer may be the result of either exposure to proinflammatory stimuli in the tumor microenvironment or mutational activation of upstream components in IKKNF- $\mathrm{B}$ signaling pathways (Karin et al. 2002). Further bolstering our belief in the oncogenic potential of "normal" NF-кB activated by stimuli that are extrinsic to the cancer cell were the findings that NF- $\mathrm{KB}$ can inhibit apoptosis (Beg and Baltimore 1996; Liu et al. 1996; Van Antwerp et al. 1996; Wang et al. 1996), stimulate cell proliferation (Joyce et al. 2001), as well as promote a migratory and invasive phenotype that is associated with tumor progression

Editors: Louis M. Staudt and Michael Karin

Additional Perspectives on NF-кB available at www.cshperspectives.org

Copyright (C) 2009 Cold Spring Harbor Laboratory Press; all rights reserved; doi: 10.1101/cshperspect.a000141

Cite this article as Cold Spring Harb Perspect Biol 2009;1:a000141 
M. Karin

(Huang et al. 2001). Concurrently, we became cognizant of a large body of epidemiological and experimental data providing new support for a causal link between inflammation and cancer, an association that was first proposed by Virchow during the 19th century (Balkwill and Mantovani 2001). Considering these findings, together with sightings of activated NF$\kappa \mathrm{B}$ in a large number of cancers, most of which are not associated with genetic alterations in NF-кB, IKK, or upstream components of this signaling system, we proposed that NF- $\mathrm{KB}$ may provide a critical mechanistic link between inflammation and cancer (Karin et al. 2002). During the past seven years, this proposal has been subjected to intense scrutiny by a number of labs, in a variety of experimental systems, and although complex and occasionally unpredictable, the role of the NF- $\mathrm{\kappa B}$ signaling system in bridging inflammation and cancer is currently well appreciated (Karin 2006). It was also found that some IKK subunits $(\mathrm{IKK} \alpha)$ and closely related protein kinases (e.g., IKKe) can play NF- $\kappa \mathrm{B}$ independent roles in a variety of cancers (Boehm et al. 2007; Luo et al. 2007). In addition, new work has resulted in the identification of cancer-associated mutations in upstream components of the IKK-NF-кB signaling system that can lead to cell autonomous activation of NF-кB in multiple myeloma (Annunziata et al. 2007; Keats et al. 2007). The goal of this article is to review the experimental evidence for the pathogenic function of NF- $\mathrm{KB}$ in cancer and discuss whether and how IKKNF-кB targeted interventions can be used in cancer prevention and/or therapy.

\section{NF- $\kappa B$ IN LYMPHOID MALIGNANCIES: FROM CELL AUTONOMY TO PARACRINE EFFECTS}

As mentioned above, the first hint to a link between NF- $\mathrm{BB}$ and cancer had emerged with the cloning of RelA and the realization of its close kinship to the viral oncoprotein v-Rel and its cellular homolog c-Rel (Gilmore 2003). Soon thereafter, the Bcl-3 oncoprotein, a product of a gene activated by chromosomal translocation in B-cell chronic lymphocytic leukemia, was identified as a member of the IкB family (Franzoso et al. 1992; Bours et al. 1993). Later, the NF- $\kappa B 2$ gene was also found to be rearranged in $\mathrm{B}$ - and $\mathrm{T}$-cell lymphomas, giving rise to a truncated NF- $\mathrm{\kappa B} 2 / \mathrm{p} 100$ protein devoid of the IкB-like activity that is exhibited by native p100 (Neri et al. 1991). These early findings led to an extensive search for mutations affecting the IкB-NF-кB system in other lymphoid malignancies. This effort, however, has netted few new results other than those described previously. For instance, ІкB $\alpha$ gene mutations were detected in Hodgkin's lymphoma (Cabannes et al. 1999), but their contributions to pathogenesis is still not clear. Eventually, this has led to a broader view of the role played by NF- $\kappa \mathrm{B}$ in tumorigenesis, according to which, mutations that cause NF$\kappa \mathrm{B}$ activation in malignant cells may occur in genes coding for signaling proteins that feed into the IKK-NF- $\mathrm{B}$ module. Indeed, translocations that lead to Bcl-10 overexpression and activation of IKK-NF-кB signaling were identified in MALT lymphomas (Willis et al. 1999). Another product of a chromosomal translocation in MALT lymphoma is MALT1, a protein with paracaspase homology that interacts with Bcl-10 and Carma-1 to yield IKK activation (Uren et al. 2000). Given its well established antiapoptotic function, especially in B cells (Grossmann et al. 2000; Gugasyan et al. 2000; Pasparakis et al. 2002), activation of NF- $\kappa B$ through MALT1 or Bcl-10 is thought to be one of the hallmarks and a key pathogenic event in MALT lymphoma.

Another B-cell malignancy in which the CARD11:MALT1:Bcl-10 complex plays an important pathogenic role is diffuse large B-cell lymphoma (DLBCL). Staudt and coworkers made extensive use of DNA microarray technology to identify genes that are misregulated in different types of DLBCL and arrived at the conclusion that NF- $\mathrm{\kappa B}$ is constitutively active in activated B-cell-like (ABC)-DLBCL, but not in germinal center B-cell-like (GCB)-DLBCL (Davis et al. 2001). Importantly, constitutively active NF- $\mathrm{KB}$ is required for the survival of ABC-DLBCL (Davis et al. 2001). An shRNAbased screen for genes, whose expression is 
required for the survival of DLBCL cells, identified CARD11 as the driver of constitutive $\mathrm{NF}-\kappa \mathrm{B}$ activity in ABC-DLBCL (Ngo et al. 2006). Furthermore, the CARD11 gene was found to be mutated in about $10 \%$ of $\mathrm{ABC}$ DLBCL (Lenz et al. 2008). The mutations all affect residues within the coiled-coil domain of CARD11 and generate a protein that is a constitutive activator of IKK-NF- $\kappa \mathrm{B}$ signaling. These results indicate that in a subpopulation of ABC-DLBCL, CARD11 acts as a bona fide oncogene and that its coiled-coil domain serves a negative regulatory function. However, we still do not know what causes the CARD11dependent activation of NF- $\kappa \mathrm{B}$ in the remaining $90 \%$ of DLBCL. Nonetheless, it is clear that the CARD11:MALT1:Bcl-10 complex is an important driver of malignant B-cell survival in more than one type of lymphoma.

Another lymphoid malignancy associated with NF- $\kappa \mathrm{B}$ activation is multiple myeloma. Although activated NF- $\kappa \mathrm{B}$ is a common feature of multiple myeloma, no mutations in $\mathrm{NF}-\kappa \mathrm{B}$ or I $\mathrm{B}$ encoding genes have been discovered in this disease either. However, extensive genetic analysis of primary tumors and multiple myeloma cell lines have revealed a number of mutations in genes encoding upstream signaling molecules that lead to stabilization and accumulation of NF- $\mathrm{BB}$ inducing kinase (NIK), a member of the MAPK kinase kinase (MAP3K) family (Annunziata et al. 2007; Keats et al. 2007). Normally, NIK is a very unstable protein whose activity is kept at a low level because of its rapid turnover (Vallabhapurapu et al. 2008). However, mutations in genes encoding components of an ubiquitin ligase complex responsible for NIK turnover or in the NIK gene itself result in accumulation and selfactivation of NIK. These mutations include alterations in either NIK or in TRAF3 that disrupt the interactions between the two proteins (Annunziata et al. 2007; Keats et al. 2007). Normally, the binding of TRAF3 to NIK in nonstimulated cells results in the recruitment to NIK of a protein complex composed of the ubiquitin ligases cIAP1 or cIAP2 and TRAF2 and this complex leads to degradative NIK ubiquitination (Vallabhapurapu et al. 2008).
Other multiple myeloma-linked mutations include large deletions affecting the closely linked CIAP1 and CIAP2 loci, resulting in the complete absence of their protein products, thereby preventing degradative polyubiquitination of NIK (Annunziata et al. 2007; Keats et al. 2007). More rare mutations abolish the expression of TRAF2 (Keats et al. 2007). Although related in structure to TRAF3, TRAF2 does not directly interact with NIK and instead serves as an activating ubiquitin ligase for cIAP1 and cIAP2, enhancing their ability to polyubiquitinate NIK (Vallabhapurapu et al. 2008). Based on its known ability to activate IKK $\alpha$ and thereby induce processing of NF- $\mathrm{B} 2 / \mathrm{p} 100$ to $\mathrm{NF}-\kappa \mathrm{B} 2 / \mathrm{p} 52$, it was expected that the elevated and activated NIK in multiple myeloma exerts its oncogenic activity via IKK $\alpha$ (Senftleben et al. 2001). It was, therefore, much of a surprise that only IKK $\beta$ inhibition and not IKK $\alpha$ depletion affected the proliferation and survival of multiple myeloma cells (Annunziata et al. 2007).

NF- $\kappa \mathrm{B}$ can also be activated in several other lymphoid malignancies as a result of infection with either DNA or RNA tumor viruses. For instance, Epstein-Barr virus (EBV) activates NF- $\kappa \mathrm{B}$ through expression of latent membrane protein 1 (LMP1), a protein that can induce lymphomas when expressed in transgenic mice (Eliopoulos and Young 2001; Thornburg et al. 2006). Curiously, LMP1 can induce NIKdependent NF-кB2/p100 processing (Luftig et al. 2004), but the specific contribution of $\mathrm{NF}-\kappa \mathrm{B} 2 / \mathrm{p} 52$ formation to lymphomagenesis is not entirely clear, unless NF-кB2/p100 acts as a general NF- $\kappa \mathrm{B}$ inhibitor in nontransformed lymphocytes. Kaposi Sarcoma-associated herpesvirus (KSHV) can induce primary effusion lymphoma (PEL) through expression of vFLIP, a viral version of the cFLIP protein that can lead to IKK activation (Liu et al. 2002). Inhibition of NF- $\mathrm{KB}$ induces the apoptotic death of PEL cells (Keller et al. 2000). Human T-cell lymphoma virus (HTLV) leads to NF$\kappa \mathrm{B}$ activation through expression of the Tax oncoprotein, which binds to IKK $\gamma / \mathrm{NEMO}$ and induces IKK activation (Carter et al. 2001). Tax can also activate the alternative, 
M. Karin

IKK $\alpha$-dependent, NF- $\kappa$ B pathway (Xiao et al. 2001), but in light of what has been discussed previously, the contribution of alternative NF-кB signaling to lymphomagenesis is not entirely clear.

\section{NF- ONCOGENIC COOPERATION BETWEEN NEIGHBORS}

Whereas the involvement of NF- $\mathrm{B}$ and its activators in lymphomagenesis was somewhat anticipated, identifying a role for $\mathrm{NF}-\kappa \mathrm{B}$ in solid malignancies required a conviction in this possibility and the use of specialized mouse models, in which tumor induction depends on inflammation, thus mimicking inflammationdriven cancers in humans. The first such model was a mouse model for colitis-associated cancer (CAC), a type of colon cancer that appears in patients suffering from ulcerative colitis, a chronic inflammatory bowel disease. In this particular model, mice are given azoxymethane (AOM), a procarcinogen that undergoes metabolic activation in intestinal epithelial cells (IEC) and can give use to oncogenic mutations, such as those that lend to activation of $\beta$ catenin (Greten et al. 2004). Although $\beta$-catenin is the most commonly activated oncogene in colon cancer (Morin et al. 1997), AOM alone gives rise to only a small number of large bowel adenomas, which can be strongly augmented through concomitant induction of colonic inflammation that in this model is elicited by repeated administration of the irritant dextrane sulfate sodium (DSS). Using the AOM and DSS model for CAC induction (Okayasu et al. 1996) and conditional disruption of the $I k k \beta$ gene in mice, we found that IKK $\beta$-driven $N F-\kappa B$ activation in IEC is essential for the development of colonic adenomas (Greten et al. 2004). The oncogenic role of NF- $\kappa B$ in IEC appears to be mediated through its antiapoptotic function (Lin and Karin 2003), mainly through induction of $\mathrm{Bcl}-\mathrm{X}_{\mathrm{L}}$, which prevents the apoptotic elimination of premalignant cells (Greten et al. 2004). In addition to its cell-autonomous function in premalignant IEC, IKK $\beta$-driven NF- $\mathrm{B}$ contributes to CAC development by acting within myeloid cells, most likely within lamina propria macrophages. Activation of NF- $\mathrm{\kappa B}$ in these cells was found to stimulate the proliferation of premalignant IEC, through the secretion of growth factors (Greten et al. 2004). No effect of myeloid IKK $\beta$ on the survival of IEC was found.

We have searched for NF-кB-dependent factors produced by lamina propria macrophages that stimulate CAC growth. As earlier experiments suggested that IL- 6 produced by $\mathrm{T}$ cells at late stages of CAC progression enhances adenoma growth (Becker et al. 2004), we first examined the involvement of this cytokine in early tumor promotion. We confirmed that during CAC development, IL-6 is mainly produced by lamina propria macrophages and dendritic cells as initially suspected (Grivennikov et al. 2009). Most importantly, ablation of IL-6 reduced both the multiplicity and size of colonic adenomas in AOM plus DSS-treated mice (Grivennikov et al. 2009). However, unlike the ablation of IKK $\beta$ in myeloid cells, which had no effect on the survival of IEC and their premalignant derivatives (Greten et al. 2004), the IL-6 deficiency compromised IEC survival (Grivennikov et al. 2009). Both the proliferative and the survival effects of IL- 6 are mediated through activation of the STAT3 transcription factor and the ablation of STAT3 in IEC dramatically compromised IEC survival and greatly reduced CAC growth (Grivennikov et al. 2009). These results suggest that some of the protumorigenic effects of NF- $\mathrm{\kappa B}$ activation in myeloid cells could be caused by paracrine signaling to STAT3 in epithelial cells (Fig. 1). In addition, these results suggest that the proproliferative and prosurvival effect of myeloid cell NF-кB on premalignant IEC is predominantly mediated via other cytokines. Likely candidates are IL-22, IL-11, and EGF family members (Bollrath et al. 2009; Pickert et al. 2009). IL-12 family members also play an important role in CAC development and growth, as ablation of the gene encoding the p40 subunit, which is common to both IL-12 and IL-23, greatly diminishes CAC induction and growth (Gri-vennikov and Karin, unpubl.). However, the effect of these cytokines on IEC 


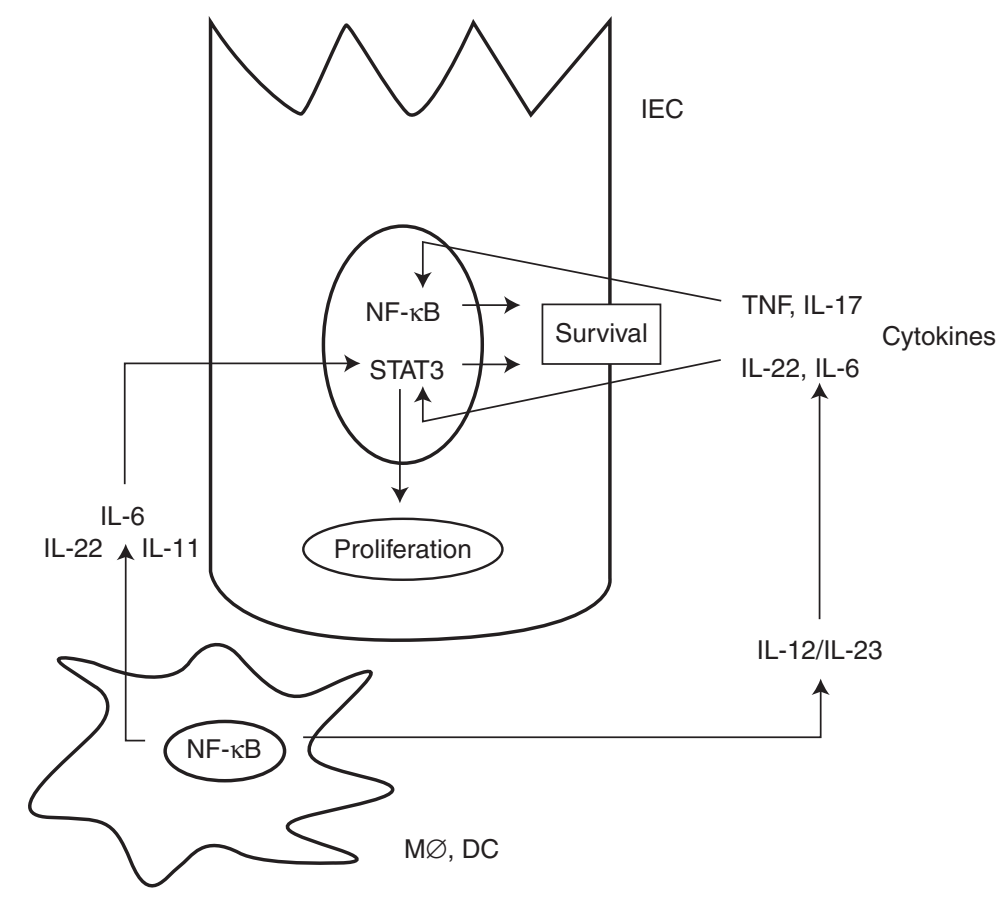

Figure 1. NF-кB-dependent interactions between myeloid (MØ, DC) and intestinal epithelial cells (IEC) drive the development of colitis-associated cancer.

appears to be indirect, because IEC do not express IL-12/IL-23 receptors.

Activation of NF- $\mathrm{BB}$ in IEC results in induction of antiapoptotic genes that increase the survival of premalignant cells. In $\mathrm{M} \varnothing$, however, the activation of NF- $\mathrm{BB}$ results in production of cytokines, particularly IL-6, IL-11, and IL-22, which drive the proliferation of premalignant IEC. IL-6 and IL-11 exert their proliferative effect via STAT3, which further synergizes with NF- $\mathrm{KB}$ to increase the expression of survival genes. NF- $\mathrm{KB}$ also drives the production of IL-12/IL-23 cytokines, which amplify the production of prosurvival cytokines.

An alternative mode of action for myeloid cell NF-кB was suggested by Hagemann and coworkers (Hagemann et al. 2008), who found that inhibition of NF- $\mathrm{\kappa B}$ activity in tumorassociated macrophages (TAM) through the conditional deletion of IKK $\beta$ re-educates these immunosuppressive and protumorigenic cells to acquire a cytotoxic, antitumorigenic phenotype. Importantly, the adoptive transfer of TAMs infected with a dominant-negative
IKK $\beta$ adenovirus into mice bearing transplanted ovarian carcinomas resulted in inhibition of tumor growth, which was associated with enhanced tumoricidal activity (Hagemann et al. 2008). Thus, according to this work, another tumor promoting function exerted by IKK $\beta$ and NF- $K B$ in TAM is the maintenance of a tumor suppressive phenotype characterized by low levels of inducible NO synthase (iNOS) and IL-12 expression, and high levels of IL-10, TNF- $\alpha$, and arginase-1. Exactly how NF-кB maintains this immunosuppressive phenotype is not clear, but inhibition of NF- $\mathrm{BB}$ in TAMs was seen to result in up-regulation of iNOS and IL-12, leading to elevated production of tumoricidal $\mathrm{NO}$ and enhanced activation of NK-cell-mediated antitumor immunity, respectively (Hagemann et al. 2008). It remains to be seen whether this outcome of IKK $\beta$ inhibition in myeloid cells also contributes to the results obtained in the CAC model that were described previously, as well as those found in the liver cancer model described later, where IKK $\beta$ activation in liver myeloid 
M. Karin

cells also promotes tumor development. So far, however, inhibition of IKK $\beta$-driven NF- $\kappa$ B in lamina propria myeloid cells was not found to result in increased IL-12 production (Greten et al. 2004).

\section{THE COMPLEX ROLE OF NF- $\kappa$ B IN HEPATOCELLULAR CARCINOMA: LOCATION, LOCATION, LOCATION}

Another inflammation-linked cancer is hepatocellular carcinoma (HCC), the most common form of liver cancer. HCC most commonly develops in the context of chronic viral hepatitis caused by either HBV or HCV infection. However, as neither virus infects mice, mouse models of HCC are not based on viral hepatitis. Nonetheless, one mouse model in which spontaneous HCC development is dependent on chronic liver inflammation is the $M d r 2^{-/-}$ knockout mouse, which develops hepatosteatosis caused by defective phospholipid and bile acid export (Mauad et al. 1994). Hepatosteatosis in these mice leads to low grade hepatitis, which eventually results in the development of HCC. In this model, Pikarsky and colleagues have examined the role of hepatocyte NF- $\mathrm{B}$ by expressing a nondegradable form of IкB $\alpha$ from a doxycycline-regulated liver-specific promoter (Pikarsky et al. 2004). Inhibition of NF- $\kappa \mathrm{B}$ activation in hepatocytes of $M d r 2^{-/-}$ mice retarded and reduced HCC development. Although the initial stimulus leading to NF$\kappa \mathrm{B}$ activation in $\mathrm{Mdr2} 2^{-/-}$mice has not been fully identified, it appears to be associated with a chronic inflammatory response that is propagated via paracrine TNF- $\alpha$ production, as treatment of these mice with a neutralizing anti-TNF- $\alpha$ antibody inhibits NF- $\kappa$ B activation in hepatocytes and decreases expression of NF-кB-dependent antiapoptotic genes. The major mechanism by which NF- $\mathrm{B}$ was suggested to exert its tumor promoting function in $M d r 2^{-/-}$mice is the suppression of apoptosis (Pikarsky et al. 2004). However, the published results are also consistent with a role for hepatocyte NF- $\mathrm{BB}$ in the maintenance of chronic inflammation in $M d r 2^{-/-}$mice that is critical for tumor development.
An entirely different scenario applies to the role of NF- $\mathrm{BB}$ in HCC development in mice injected with the procarcinogen diethylnitrosamine (DEN). DEN undergoes metabolic activation in zone 3 hepatocytes and if injected into 2-week-old mice, it acts as a "complete" carcinogen that, unlike AOM, does not require assistance from concurrent inflammation. Nonetheless, DEN-induced HCC requires NF$\kappa \mathrm{B}$ activation in myeloid cells, in this case Kupffer cells, the resident liver macrophages (Maeda et al. 2005). As found in CAC, DENinduced HCC requires the NF- $\mathrm{BB}$-dependent production of IL-6 by Kupffer cells (Naugler et al. 2007) and the activation of STAT3 by IL-6 in hepatocytes (Yu and Karin, unpubl.) (Fig. 2). However, in a striking difference from CAC and HCC in $M d r 2^{-/-}$mice, development of DEN-induced HCC is strongly enhanced by inhibition of NF- $\mathrm{B}$ activation in hepatocytes through the targeted deletion of IKK $\beta$ (Maeda et al. 2005). An even more striking effect on HCC development is seen upon the conditional deletion of hepatocyte IKK $\gamma /$ NEMO (Luedde et al. 2007). In this case, the "deleted" mice exhibit spontaneous liver damage and sequentially develop hepatosteatosis, hepatitis, liver fibrosis, and HCC even without any injection of a carcinogen. Enhanced chemical hepatocarcinogenesis was also observed in hepatocytespecific $p 38 \alpha$ knockout mice (Hui et al. 2007; Sakurai et al. 2008). Mice lacking either IKK $\beta$ $\left(I k k \beta^{\Delta h e p}\right)$ or $\mathrm{p} 38 \alpha\left(p 38 \alpha^{\Delta h e p}\right)$ in their hepatocytes exhibit greatly enhanced accumulation of reactive oxygen species (ROS) in zone-3 hepatocytes after DEN exposure (Maeda et al. 2005; Sakurai et al. 2008). As a result of elevated ROS accumulation, which can be prevented by oral administration of antioxidant butylated hydroxyanisol (BHA), both $I k k \beta^{\Delta h e p}$ and $p 38 \alpha^{\text {shep }}$ mice show increased hepatocyte death. However, in the liver, an organ with unusually high regenerative capacity, cell death triggers compensatory proliferation. We proposed that compensatory proliferation acts as a tumor promoter in situations in which liver tumorigenesis is driven by circles of injury and regeneration, rather than low-grade chronic inflammation, and is therefore the major cause 


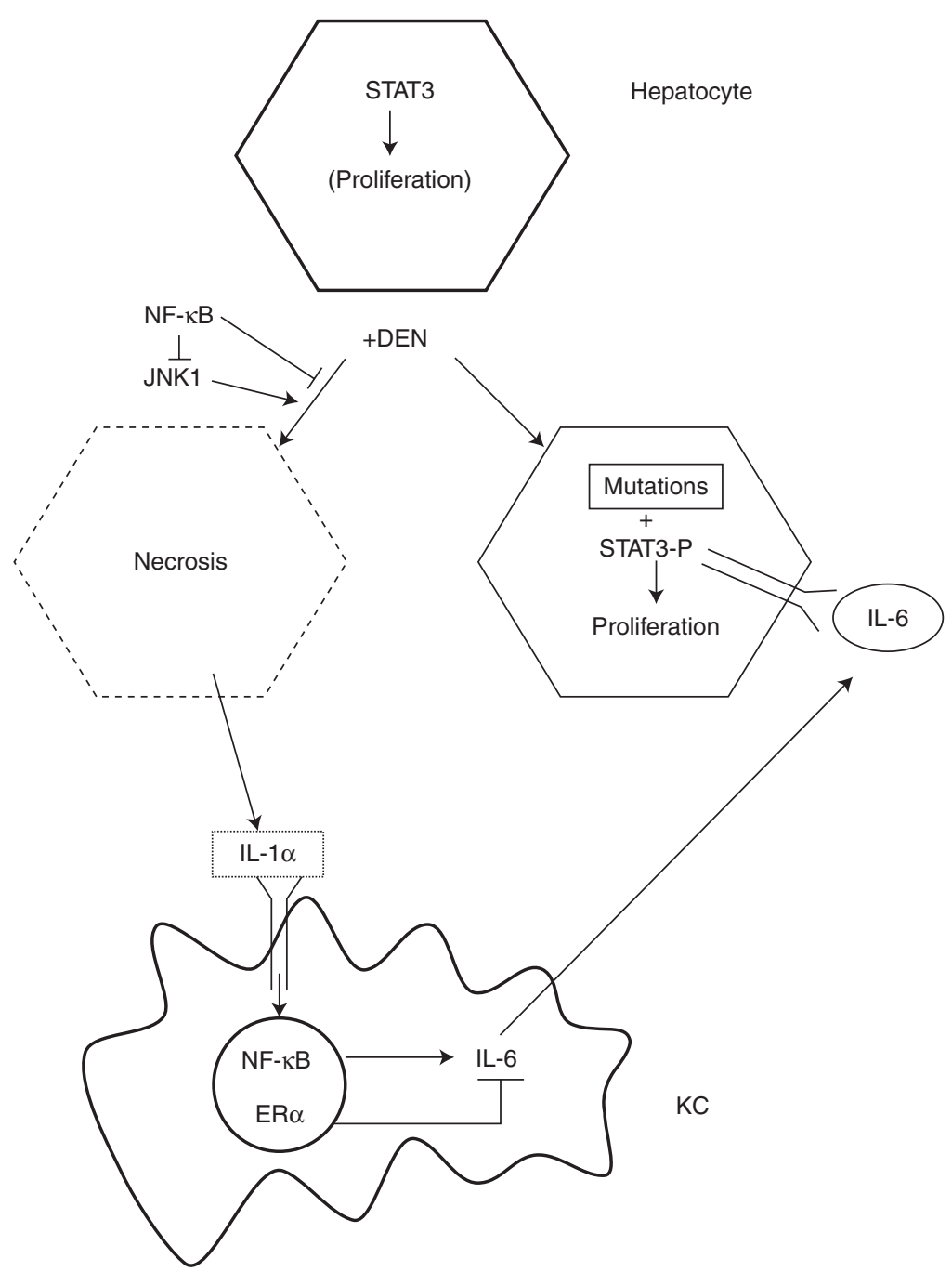

Figure 2. NF- $\mathrm{B}$ in Kupffer cells (KC) and STAT3 in hepatocytes drive the development of DEN-induced hepatocellular carcinoma (HCC).

of enhanced hepatocarcinogenesis in $I k k \beta^{\Delta h e p}$, $p 38 \alpha^{\Delta h e p}$, and $I k k \gamma^{\Delta h e p}$ mice (Sakurai et al. 2006). Indeed, in all of these mutant-mouse strains, administration of BHA prevents liver damage and inhibits compensatory proliferation and, where tested, it fully blocks the increase in hepatocellular carcinogenesis (Maeda et al. 2005; Luedde et al. 2007; Sakurai et al. 2008). Reduced hepatocyte death, compensatory proliferation, and hepatocarcinogenesis were also seen upon crossing of $I k k \beta^{\Delta h e p}$ mice with JNK1-deficient Jnk1 $1^{-}$mice (Sakurai et al. 2006). Contrary to IKK $\beta$, JNK1 promotes the death of DEN-exposed hepatocytes and at the same time stimulates compensatory proliferation. Furthermore, ablation of hepatocyte IKK $\beta$ results in increased JNK activity (Maeda et al. 2005) because of increased ROS accumulation (Kamata et al. 2005). Collectively, these results indicate that the major function of hepatocyte NF- $\mathrm{KB}$ in DEN-administered mice or even in unchallenged mice is to maintain hepatocyte survival and liver homeostasis, in part by suppressing cytotoxic ROS accumulation. 
M. Karin

In the mouse, after 2 weeks of age, most hepatocytes withdraw from the cell cycle and arrest in $\mathrm{G}_{0}$. The same applies to human liver, although in this case cell-cycle withdrawal occurs at a later time point. Carcinogen exposure in a tissue that does not undergo active proliferation, such as the uninjured liver, can not easily give rise to cancer. Therefore, any injury or an alteration that augments hepatocyte death and gives rise to compensatory proliferation will enhance HCC development. However, in the colon, IEC undergo continuous renewal and the absence of NF- $\mathrm{BB}$ in such cells does not further enhance cell proliferation, resulting in a net increase in cell death. Under these circumstances, increased elimination of premalignant cells is the dominant outcome of NF- $\mathrm{KB}$ inhibition, resulting in reduced tumorigenesis. Thus, by acting in different cells subject to different tissue kinetics, NK-кB can either enhance or suppress tumorigenesis.

Administration of DEN results in induction of oncogenic mutations in some hepatocytes and the necrotic death of others. Necrotic hepatocytes release IL- $1 \alpha$ that leads to activation of NF- $\mathrm{B}$ in Kupffer cells. This results in induction of IL-6, which is negatively regulated by estrogen receptor $(E R) \alpha$. The IL- 6 produced by Kupffer cells acts on neighboring hepatocytes to activate STAT3 and induce the expression of proliferation-promoting genes. If these cells harbor oncogenic mutations, their proliferation would eventually give rise to HCC.

Importantly, in all of the models discussed so far, inhibition of NF-кB in myeloid cells reduces tumor development. Furthermore, as found in $\mathrm{CAC}$, the major protumorigenic effect of NF- $\mathrm{B}$ in Kupffer cells is mediated through the induction of IL-6, which is inhibited by activation of estrogen receptor (ER) $\alpha$ (Naugler et al. 2007). We found that DEN administration, especially in $I k k \beta^{\Delta h e p}$ and $p 38 \alpha^{\Delta h e p}$ mice, gives rise to $\mathrm{NF}-\kappa \mathrm{B}$ activation in Kupffer cells in a manner that depends on induction of hepatocyte necrosis (Sakurai et al. 2008). In this case, the primary mediator of NF- $\kappa \mathrm{B}$ activation in Kupffer cells is IL- $1 \alpha$, which is released in large amounts by necrotic hepatocytes (Fig. 2). Importantly, mice that are deficient in IL-1 receptor or its adaptor protein MyD88 are quite refractory to DEN-induced hepatocarcinogenesis, demonstrating the importance of the IL- $1 \alpha$-mediated cross talk between dying hepatocytes and Kupffer cells (Sakurai et al. 2008).

Interestingly, the incidence of HCC is three to five times higher in men than in women (Bosch et al. 2004) and the same applies to DEN-induced HCC in mice (Naugler et al. 2007). As mentioned previously, production of IL- 6 by Kupffer cells exposed to IL- $1 \alpha$ or other $\mathrm{NF}-\kappa \mathrm{B}$ activators is negatively regulated by $\mathrm{ER} \alpha$. Thus, DEN-treated female mice produce less IL- 6 than similarly treated male mice and contain less activated STAT3 in their hepatocytes (Naugler et al. 2007). Ablation of the Il6 gene abolishes the gender difference in HCC induction, whereas ovariectomy enhances IL-6 production and augments HCC induction in female mice (Naugler et al. 2007). It is likely that gender-specific differences in IL-6 expression also affect the incidence of human HCC, as serum IL-6 is higher after menopause (Jilka et al. 1992; Ershler and Keller 2000) and postmenopausal women display higher HCC incidence than premenopausal women (Bosch et al. 2004). Recently, elevated serum IL-6 was found to be associated with rapid progression from chronic viral hepatitis to frank HCC in a large cohort of HBV-positive patients in Hong Kong (Wong et al. 2009).

\section{AN IKK ACTIVATION CASCADE IN PROSTATE CANCER: AN IKK $\beta-I K K \alpha$ RELAY}

Although HCC and CAC are clearly inflammation-linked cancers, there are many other cancers that rarely arise in the context of underlying inflammation or infection and yet are dependent on inflammatory processes, most of which occur as a consequence of tumor progression. One such cancer is prostate cancer $(\mathrm{CaP})$, which is the most common malignancy in older men. We have used the TRAMP mouse in which $\mathrm{CaP}$ development and progression are driven by expression of SV40 T antigen in prostate epithelial cells (Greenberg et al. 1995; Gingrich et al. 1996) to study the 
role of IKK signaling in prostate tumorigenesis. We first examined whether deletion of IKK $\beta$ in prostate epithelial cells has any effect on $\mathrm{CaP}$ development and found no effect whatsoever, neither on tumor development and progression, nor on the development of androgen-independent (AI) cancer after castration (Ammirante et al., in prep.). The latter results were surprising, as AI CaP usually exhibits activated NF- $\mathrm{B}$ (Gasparian et al. 2002). These findings led us to examine whether IKK $\beta$ in hematopoieticderived cells has a role in $\mathrm{CaP}$ development. Although deletion of IKK $\beta$ in the hematopoietic compartment had no effect on development and progression of primary $\mathrm{CaP}$ in TRAMP mice, it slowed down the development of AI $\mathrm{CaP}$ after castration and inhibited the appearance of metastases (Ammirante et al., in prep.). Similar results were obtained in a different model based on subcutaneous implantation of the androgen-dependent $(\mathrm{AD})$ mouse $\mathrm{CaP}$ cell line, Myc-CaP. In this case, the tumors were allowed to grow to a size of $1000 \mathrm{~mm}^{3}$ before castration of the hosts, which subjects the tumor to androgen deprivation, causing near complete regression because of necrotic and apoptotic death of $\mathrm{CaP}$ cells, which depend on androgens (testosterone) for survival. However, through mechanisms that are not entirely understood, almost as soon as the original $\mathrm{AD} \mathrm{CaP}$ disappear, an $\mathrm{AI}$ tumor starts growing, as is often the case in prostate cancer patients undergoing androgen ablation therapy. Silencing of endogenous IKK $\beta$ in Myc-CaP cells had no effect on their primary tumorigenic growth, regression upon castration, and regrowth as $\mathrm{AI} \mathrm{CaP}$. However, deletion of IKK $\beta$ in bone-marrow-derived cells (BMDC) of the host substantially slowed down the regrowth of $\mathrm{AI} \mathrm{CaP}$ in castrated tumor-bearing mice (Ammirante et al., in prep.). A similar delay in the regrowth of $\mathrm{AI} \mathrm{CaP}$ was seen upon treatment of tumor-bearing hosts with IKK $\beta$ inhibitors. As found in both the CAC and HCC models described above, IKK $\beta$ ablation in BMDC-inhibited STAT3 activation in $\mathrm{CaP}$ cells and a STAT3 inhibitor slowed down the emergence of AI CaP (Ammirante et al., in prep.).
Curiously, the development of $\mathrm{AI} \mathrm{CaP}$ is associated with the accumulation of activated IKK $\alpha$ in nuclei of CaP cells (Ammirante et al., in prep.). Accumulation of nuclear IKK $\alpha$ was previously found to be linked with and necessary for metastatic progression of $\mathrm{CaP}$ in TRAMP mice (Luo et al. 2007). Furthermore, accumulation of nuclear IKK $\alpha$ correlated with progression and clinical grade in human $\mathrm{CaP}$ (Luo et al. 2007). Importantly, IKK $\beta$ in $\mathrm{BMCD}$ is required for activation of nuclear IKK $\alpha$ in CaP cells through the production of IKK $\alpha$-activating cytokines. The silencing of $\mathrm{IKK} \alpha$ in Myc-CaP cells delays the emergence of $\mathrm{AI} \mathrm{CaP}$ as effectively as the inhibition of IKK $\beta$ does.

The mechanism by which nuclear IKK $\alpha$ contributes to the growth of $\mathrm{AI} \mathrm{CaP}$ remains to be determined, but previous studies on metastatic progression in TRAMP mice revealed that nuclear IKK $\alpha$ enhances metastatic progression by repressing transcription of the metastasis inhibitor maspin (Luo et al. 2007). Although the details of maspin repression by IKK $\alpha$ are not fully known, it is clear that it does not involve activation of either canonical or noncanonical NF- $\mathrm{B}$ signaling (Luo et al. 2007). Repression of maspin requires the kinase activity of $\operatorname{IKK} \alpha$, suggesting that it is exerted through the phosphorylation of another protein, possibly a component of chromatin, which is involved in the regulation of maspin transcription. It remains to be seen whether repression of maspin contributes to the emergence of $\mathrm{AI} \mathrm{CaP}$, but maspin was shown to have antiproliferative and proapoptotic activities (Lockett et al. 2006).

Concurrent with the death of $\mathrm{AD} \mathrm{CaP}$, androgen withdrawal results in massive inflammatory infiltration of the tumor remnant. Most immune and inflammatory cell types are present within the regressing tumor transiently and only B cells are the ones that remain within the newly emerging $\mathrm{AI} \mathrm{CaP}$ for at least 3 weeks after castration (Ammirante et al., in prep.). Curiously, we found that about $90 \%$ of human prostate tumors, but not normal, hyperplastic, or malignant tissue, contain B cells as well. Most importantly, B cells, but not T cells, 


\section{Karin}

were found to be required for the rapid emergence of AI tumors as well as for IKK $\alpha$ and STAT3 activation in CaP cells of such tumors (Ammirante et al., in prep.). Most likely, B cells are required for production of cytokines that lead to IKK $\alpha$ and STAT3 activation within newly emerging AI CaP cells (Fig. 3). The activation of IKK $\alpha$ and STAT3 is likely to be required for the survival and proliferation of these cells.

In androgen-dependent (AD) $\mathrm{CaP}, \mathrm{IKK} \alpha$, and STAT3 are not activated and are located in the cytosol. Androgen ablation results in the death of most $\mathrm{AD} \mathrm{CaP}$ cells. In response to the release of inflammatory mediators by the dying $\mathrm{AD} \mathrm{CaP}$ cells, inflammatory and immune cells, including B cells, are recruited into the tumor remnant. In these tumor-infiltrating $B$ cells, IKK $\beta$ is activated, resulting in the production of NF-кB-dependent cytokines that lead to activation of STAT3 and nuclear translocation of activated IKK $\alpha$ in remaining CaP cells. STAT3 and IKK $\alpha$ promote the survival of cells that have become independent of androgens, leading to the development of AI CaP. Because of the presence of nuclear $\mathrm{IKK} \alpha, \mathrm{AI} \mathrm{CaP}$ is often metastatic.

In summary, the findings described previously indicate that even a cancer whose development is not associated with an underlying inflammatory condition depends on an NF$\kappa \mathrm{B}$-regulated inflammatory response. In the case of prostate cancer, tumor-associated inflammation is part of normal progression, but can also be elicited and accelerated as a result of therapy (in this case, androgen ablation)induced death of the primary tumor. It is possible that in both cases, the localized tumorassociated inflammatory response is triggered by the necrotic death of malignant cells, either as the result of hypoxia during normal progression or as the consequence of therapeutic intervention. In the prostate cancer models described previously, the inflammatory response elicited by androgen deprivation is a major contributor to the emergence of AI CaP. The dependence of this response on IKK $\beta, B$ cells, STAT3, and IKK $\alpha$ (Fig. 3) suggests that

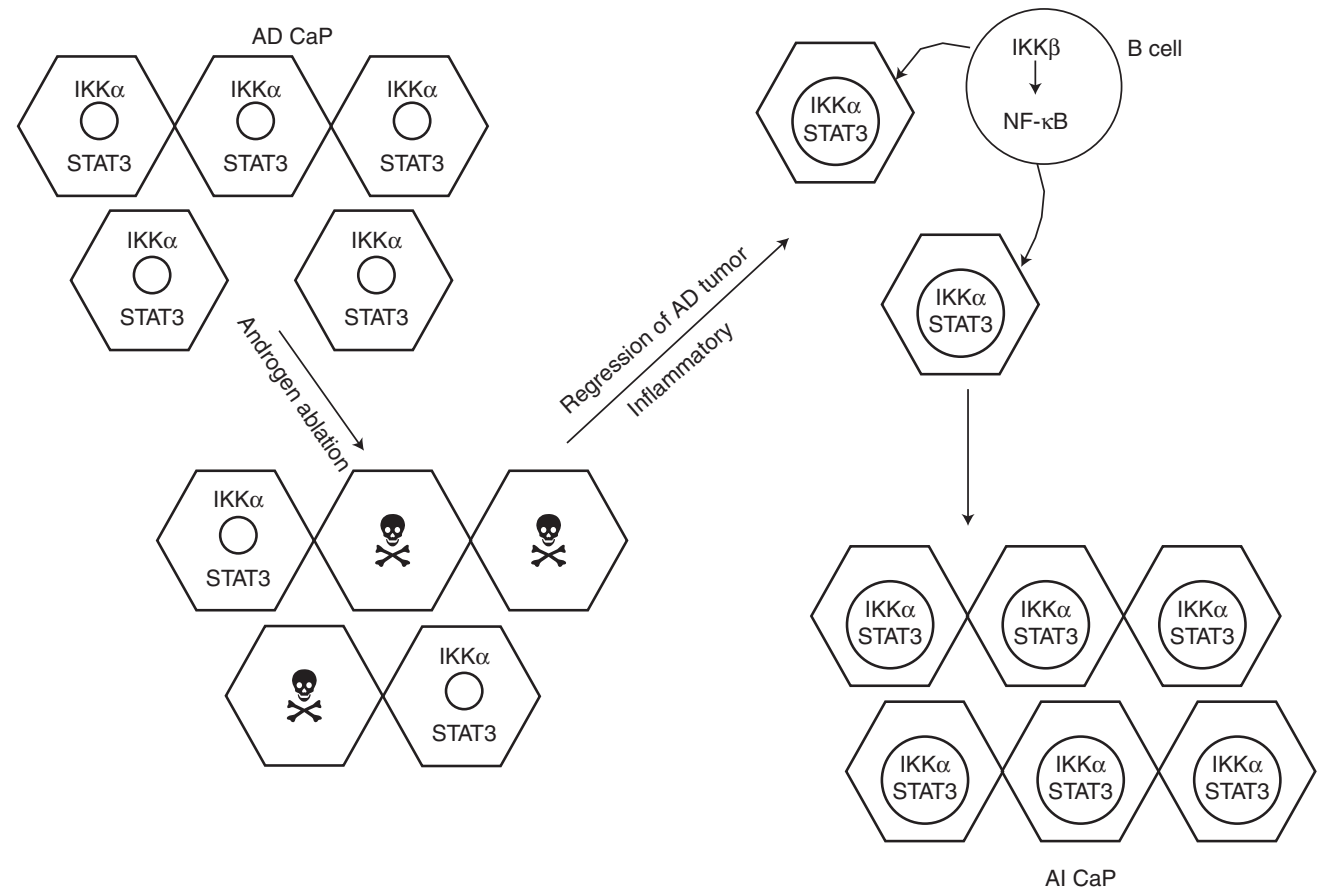

Figure 3. IKK $\beta$-IKK $\alpha$ cross talk drives the development of androgen-independent (AI) prostate carcinoma $(\mathrm{CaP})$. 
therapeutic interventions targeting any of these four elements may be used to improve the outcome of androgen ablation therapy and delay the appearance of $\mathrm{AI} \mathrm{CaP}$.

\section{CONCLUSIONS AND TRANSLATIONAL IMPLICATIONS}

In the three types of epithelial cancers described previously, inactivation of IKK $\beta$ in premalignant tumor progenitors or in the neoplastic cell itself can either inhibit tumor development (CAC), enhance tumor development (HCC), or have no discernable effect $(\mathrm{CaP})$. However, in all three cancers, the inactivation or inhibition of IKK $\beta$ in cells of the hematopoietic compartment (lamina propria macrophages, Kupffer cells, or B cells) inhibits tumor growth and progression. We assume that the tumor-promoting effect of IKK $\beta$ in such cells is mediated via $\mathrm{NF}-\kappa \mathrm{B}$ and at least in two cases (CAC and HCC), we know that it depends, at least in part, on the production of the NF- $\mathrm{\kappa B}$ regulated cytokine IL-6. In all three cases, NF- $\mathrm{B}$ signaling in cells of the hematopoietic compartment results in activation of STAT3, a transcription factor that controls the expression of proliferative and survival genes in premalignant cells and their fully neoplastic derivatives. In one case $(\mathrm{CaP}), \mathrm{IKK} \beta$ signaling in tumorinfiltrating lymphocytes results in the accumulation of activated IKK $\alpha$ in cancer cell nuclei. Thus, it can be generalized that IKK $\beta$ dependent signaling to NF- $\mathrm{KB}$ in tumorassociated inflammatory and immune cells results in the production of cytokines that activate signaling pathways that stimulate the proliferation and enhance the survival of malignant carcinoma cells.

These findings suggest that regardless of the direct effect of NF- $\mathrm{BB}$ on the survival of neoplastic cells, IKK $\beta$ inhibition can be used to slow down tumor growth and enhance susceptibility to cytocidal therapeutics (e.g., genotoxic chemicals, microtubule disruptors, ionizing radiation, and apoptosis-inducing cytokines). In this regard, it is important to realize that the mere disruption of NF- $\kappa \mathrm{B}$ or STAT3 signaling does not lead to cell death.
Hence, the requirement for classical cytocidal therapy for which IKK $\beta$ inhibitors can serve as adjuvants.

It should also be recognized that unless the cytocidal agent being used in conjunction with an IKK $\beta$ or another NF- $\kappa \mathrm{B}$ inhibitor has a wide safety margin, the systemic inhibition of NF- $\mathrm{NB}$ function may result in enhanced toxicity to normal cells and tissues. Two ways to circumvent this problem are: (a) direct the IKK $\beta$ or NF- $\mathrm{NB}$ inhibitor to the relevant inflammatory or immune cell type; and (b) direct the cytocidal therapy to the neoplastic cell. Another potential complication of IKK $\beta$ or $\mathrm{NF}-\kappa \mathrm{B}$ inhibition is long-lasting immune suppression and unpredictable effects on the inflammatory response. For instance, we have found that instead of reducing sepsis-induced inflammation, systemic administration of a specific IKK $\beta$ inhibitor or the ablation of IKK $\beta$ in myeloid cells resulted in greatly enhanced inflammation and mortality driven by elevated IL-1 $\beta$ production in mice infected with bacteria or challenged with endotoxin (Greten et al. 2007). Thus, a great deal of caution needs to be exerted during clinical development of IKK $\beta$ inhibitors as adjuvants to chemotherapy or radiation. Limiting the duration of treatment with an IKK $\beta$ inhibitor to a short period preceding or concurrent with cytocidal therapy may provide a solution to this potential complication.

Given the complexities and unpredictable nature of anti-IKK $\beta$ therapy, it is worthwhile considering a more specific approach that targets the IKK $\beta$-dependent cytokine responsible for tumor growth and survival. For instance, in the case of HCC and CAC, it may make sense to target IL- 6 by the use of antiIL-6 receptor antibodies. Although the cytokines that are critical for the growth of AI CaP and its metastatic spread remain to be identified, our initial analysis suggests that they may be RANK ligand (RANKL) or lymphotoxin (LT) (Luo et al. 2007). As both anti-RANKL and anti-LT therapeutics have already been developed for other indications, it is worthwhile to assess their effect on the emergence of $\mathrm{AI} \mathrm{CaP}$ and its progression into metastatic disease, first 
M. Karin

in animal models and if positive, in prostate cancer patients receiving androgen ablation therapy.

In summary, much has been learned about the role of inflammation and inflammatory processes in the pathogenesis of cancer by studying the oncogenic functions of NF- $\mathrm{kB}$. It is our hope that the next stage in this long endeavor would see this basic knowledge arriving at the bedside to result in new and improved cancer therapies and preventive agents.

\section{REFERENCES}

Annunziata CM, Davis RE, Demchenko Y, Bellamy W, Gabrea A, Zhan F, Lenz G, Hanamura I, Wright G, Xiao W, et al. 2007. Frequent engagement of the classical and alternative NF- $\mathrm{\kappa B}$ pathways by diverse genetic abnormalities in multiple myeloma. Cancer Cell 12: 115-130.

Balkwill F, Mantovani A. 2001. Inflammation and cancer: Back to Virchow? Lancet 357: 539-545.

Becker C, Fantini MC, Schramm C, Lehr HA, Wirtz S, Nikolaev A, Burg J, Strand S, Kiesslich R, Huber S, et al. 2004. TGF- $\beta$ suppresses tumor progression in colon cancer by inhibition of IL-6 trans-signaling. Immunity 21: 491-501.

Beg AA, Baltimore D. 1996. An essential role for NF-кB in preventing TNF- $\alpha$-induced cell death. Science 274: $782-784$.

Boehm JS, Zhao JJ, Yao J, Kim SY, Firestein R, Dunn IF, Sjostrom SK, Garraway LA, Weremowicz S, Richardson $\mathrm{AL}$, et al. 2007. Integrative genomic approaches identify IKBKE as a breast cancer oncogene. Cell 129: 1065-1079.

Bollrath J, Phesse TJ, von Burstin VA, Putoczki T, Bennecke M, Bateman T, Nebelsiek T, Lundgren-May T, Canli O, Schwitalla S, et al. 2009. gp130-mediated Stat3 activation in enterocytes regulates cell survival and cell-cycle progression during colitis-associated tumorigenesis. Cancer Cell 15: 91-102.

Bosch FX, Ribes J, Diaz M, Cleries R. 2004. Primary liver cancer: Worldwide incidence and trends. Gastroenterology 127: S5-S16.

Bours V, Franzoso G, Azarenko V, Park S, Kanno T, Brown K, Siebenlist U. 1993. The oncoprotein Bcl-3 directly transactivates through $\kappa \mathrm{B}$ motifs via association with DNA-binding p50B homodimers. Cell 72: 729-739.

Cabannes E, Khan G, Aillet F, Jarrett RF, Hay RT. 1999. Mutations in the IkBa gene in Hodgkin's disease suggest a tumour suppressor role for I $\mathrm{K} \mathrm{B} \alpha$. Oncogene 18: $3063-3070$.

Carter RS, Geyer BC, Xie M, Acevedo-Suarez CA, Ballard DW. 2001. Persistent activation of NF-к B by the tax transforming protein involves chronic phosphorylation of IкB kinase subunits IKK $\beta$ and IKK $\gamma . J$ Biol Chem 276: $24445-24448$.

Davis RE, Brown KD, Siebenlist U, Staudt LM. 2001. Constitutive nuclear factor $\mathrm{\kappa B}$ activity is required for survival of activated B cell-like diffuse large B cell lymphoma cells. J Exp Med 194: 1861-1874.

Eliopoulos AG, Young LS. 2001. LMP1 structure and signal transduction. Semin Cancer Biol 11: 435-444.

Ershler WB, Keller ET. 2000. Age-associated increased interleukin-6 gene expression, late-life diseases, and frailty. Annu Rev Med 51: 245-270.

Franzoso G, Bours V, Park S, Tomita-Yamaguchi M, Kelly K, Siebenlist U. 1992. The candidate oncoprotein Bcl-3 is an antagonist of p50/NF-кB-mediated inhibition. Nature 359: 339-342.

Gasparian AV, Yao YJ, Kowalczyk D, Lyakh LA, Karseladze A, Slaga TJ, Budunova IV. 2002. The role of IKK in constitutive activation of NF- $\mathrm{\kappa B}$ transcription factor in prostate carcinoma cells. J Cell Sci 115: 141-151.

Gilmore TD. 2003. The Re1/NF-к B/I к B signal transduction pathway and cancer. Cancer Treat Res 115: 241-265.

Gingrich JR, Barrios RJ, Morton RA, Boyce BF, DeMayo FJ, Finegold MJ, Angelopoulou R, Rosen JM, Greenberg NM. 1996. Metastatic prostate cancer in a transgenic mouse. Cancer Res 56: 4096-4102.

Greenberg NM, DeMayo F, Finegold MJ, Medina D, Tilley WD, Aspinall JO, Cunha GR, Donjacour AA, Matusik RJ, Rosen JM. 1995. Prostate cancer in a transgenic mouse. Proc Natl Acad Sci 92: 3439-3443.

Greten FR, Arkan MC, Bollrath J, Hsu LC, Goode J, Miething C, Goktuna SI, Neuenhahn M, Fierer J, Paxian S, et al. 2007. NF- $\kappa B$ is a negative regulator of IL- $1 \beta$ secretion as revealed by genetic and pharmacological inhibition of IKK $\beta$. Cell 130: 918-931.

Greten FR, Eckmann L, Greten TF, Park JM, Li ZW, Egan LJ, Kagnoff MF, Karin M. 2004. IKK $\beta$ links inflammation and tumorigenesis in a mouse model of colitis-associated cancer. Cell 118: 285-296.

Grivennikov S, Karin E, Terzic J, Mucida D, Yu GY, Vallabhapurapu S, Scheller J, Rose-John S, Cheroutre H, Eckmann L, et al. 2009. IL-6 and stat3 are required for survival of intestinal epithelial cells and development of colitis-associated cancer. Cancer Cell 15: $103-113$.

Grossmann M, O'Reilly LA, Gugasyan R, Strasser A, Adams JM, Gerondakis S. 2000. The anti-apoptotic activities of Rel and RelA required during B-cell maturation involve the regulation of Bcl-2 expression. EMBO J 19: 6351-6360.

Gugasyan R, Grumont R, Grossmann M, Nakamura Y, Pohl T, Nesic D, Gerondakis S. 2000. Rel/NF-кB transcription factors: Key mediators of B-cell activation. Immunol Rev 176: $134-140$.

Hagemann T, Lawrence T, McNeish I, Charles KA, Kulbe H, Thompson RG, Robinson SC, Balkwill FR. 2008. "Reeducating" tumor-associated macrophages by targeting NF-кB. J Exp Med 205: 1261-1268.

Huang S, Pettaway CA, Uehara H, Bucana CD, Fidler IJ. 2001. Blockade of NF- $\kappa \mathrm{B}$ activity in human prostate cancer cells is associated with suppression of angiogenesis, invasion, and metastasis. Oncogene 20: 41884197.

Hui L, Bakiri L, Mairhorfer A, Schweifer N, Haslinger C, Kenner L, Komnenovic V, Scheuch H, Beug H, Wagner 
EF. 2007. p38 $\alpha$ suppresses normal and cancer cell proliferation by antagonizing the JNK-c-Jun pathway. Nat Genet 39: 741-749.

Jilka RL, Hangoc G, Girasole G, Passeri G, Williams DC, Abrams JS, Boyce B, Broxmeyer H, Manolagas SC. 1992. Increased osteoclast development after estrogen loss: Mediation by interleukin-6. Science 257: 88-91.

Joyce D, Albanese C, Steer J, Fu M, Bouzahzah B, Pestell RG. 2001. NF-кB and cell-cycle regulation: The cyclin connection. Cytokine Growth Factor Rev 12: 73-90.

Kamata H, Honda S, Maeda S, Chang L, Hirata H, Karin M. 2005. Reactive oxygen species promote TNF $\alpha$-induced death and sustained JNK activation by inhibiting MAP kinase phosphatases. Cell 120: 649-661.

Karin M. 2006. Nuclear factor-кB in cancer development and progression. Nature 441: 431-436.

Karin M, Cao Y, Greten FR, Li ZW. 2002. NF-кB in cancer: From innocent bystander to major culprit. Nat Rev Cancer 2: 301-310.

Keats JJ, Fonseca R, Chesi M, Schop R, Baker A, Chng WJ, Van Wier S, Tiedemann R, Shi CX, Sebag M, et al. 2007. Promiscuous mutations activate the noncanonical NF-кB pathway in multiple myeloma. Cancer Cell 12: $131-144$.

Keller SA, Schattner EJ, Cesarman E. 2000. Inhibition of NF- $\kappa \mathrm{B}$ induces apoptosis of KSHV-infected primary effusion lymphoma cells. Blood 96: 2537-2542.

Lenz G, Davis RE, Ngo VN, Lam L, George TC, Wright GW, Dave SS, Zhao H, Xu W, Rosenwald A, et al. 2008. Oncogenic CARD11 mutations in human diffuse large B cell lymphoma. Science 319: 1676-1679.

Lin A, Karin M. 2003. NF-кB in cancer: A marked target. Semin Cancer Biol 13: 107-114.

Liu L, Eby MT, Rathore N, Sinha SK, Kumar A, Chaudhary PM. 2002. The human herpes virus 8-encoded viral FLICE inhibitory protein physically associates with and persistently activates the Ік B kinase complex. J Biol Chem 277: 13745-13751.

Liu ZG, Hsu H, Goeddel DV, Karin M. 1996. Dissection of TNF receptor 1 effector functions: JNK activation is not linked to apoptosis while NF- $\mathrm{KB}$ activation prevents cell death. Cell 87: 565-576.

Lockett J, Yin S, Li X, Meng Y, Sheng S. 2006. Tumor suppressive maspin and epithelial homeostasis. $J$ Cell Biochem 97: 651-660.

Luedde T, Beraza N, Kotsikoris V, van Loo G, Nenci A, De Vos R, Roskams T, Trautwein C, Pasparakis M. 2007. Deletion of NEMO/IKK $\gamma$ in liver parenchymal cells causes steatohepatitis and hepatocellular carcinoma. Cancer Cell 11: 119-132.

Luftig M, Yasui T, Soni V, Kang MS, Jacobson N, CahirMcFarland E, Seed B, Kieff E. 2004. Epstein-Barr virus latent infection membrane protein 1 TRAF-binding site induces NIK/IKK $\alpha$-dependent noncanonical NF- $\kappa \mathrm{B}$ activation. Proc Natl Acad Sci 101: 141-146.

Luo JL, Tan W, Ricono JM, Korchynskyi O, Zhang M, Gonias SL, Cheresh DA, Karin M. 2007. Nuclear cytokine-activated IKK $\alpha$ controls prostate cancer metastasis by repressing Maspin. Nature 446: 690-694.

Maeda S, Kamata H, Luo JL, Leffert H, Karin M. 2005. IKK $\beta$ couples hepatocyte death to cytokine-driven compensatory proliferation that promotes chemical hepatocarcinogenesis. Cell 121: 977-990.

Mauad TH, van Nieuwkerk CM, Dingemans KP, Smit JJ, Schinkel AH, Notenboom RG, van den Bergh Weerman MA, Verkruisen RP, Groen AK, Oude Elferink RP, et al. 1994. Mice with homozygous disruption of the mdr2 P-glycoprotein gene. A novel animal model for studies of nonsuppurative inflammatory cholangitis and hepatocarcinogenesis. Am J Pathol 145: 1237-1245.

Morin PJ, Sparks AB, Korinek V, Barker N, Clevers H, Vogelstein B, Kinzler KW. 1997. Activation of $\beta$-cateninTcf signaling in colon cancer by mutations in $\beta$-catenin or APC. Science 275: 1787-1790.

Naugler WE, Sakurai T, Kim S, Maeda S, Kim K, Elsharkawy AM, Karin M. 2007. Gender disparity in liver cancer due to sex differences in MyD88-dependent IL-6 production. Science 317: 121-124.

Neri A, Chang CC, Lombardi L, Salina M, Corradini P, Maiolo AT, Chaganti RS, Dalla-Favera R. 1991. B cell lymphoma-associated chromosomal translocation involves candidate oncogene lyt-10, homologous to NF-к B p50. Cell 67: 1075-1087.

Ngo VN, Davis RE, Lamy L, Yu X, Zhao H, Lenz G, Lam LT, Dave S, Yang L, Powell J, et al. 2006. A loss-of-function RNA interference screen for molecular targets in cancer. Nature 441: 106-110.

Okayasu I, Ohkusa T, Kajiura K, Kanno J, Sakamoto S. 1996. Promotion of colorectal neoplasia in experimental murine ulcerative colitis. Gut 39: 87-92.

Pasparakis M, Schmidt-Supprian M, Rajewsky K. 2002. IкB kinase signaling is essential for maintenance of mature $\mathrm{B}$ cells. J Exp Med 196: 743-752.

Pickert G, Neufert C, Leppkes M, Zheng Y, Wittkopf N, Warntjen M, Lehr H-A, Hirth S, Weigmann B, Wirtz S, et al. 2009. STAT3 links IL-22 signaling in intestinal epithelial cells to mucosal wound healing. J Exp Med 206: 1465-1472.

Pikarsky E, Porat RM, Stein I, Abramovitch R, Amit S, Kasem S, Gutkovich-Pyest E, Urieli-Shoval S, Galun E, Ben-Neriah Y. 2004. NF-кB functions as a tumour promoter in inflammation-associated cancer. Nature 431: 461-466.

Sakurai T, He G, Matsuzawa A, Yu GY, Maeda S, Hardiman G, Karin M. 2008. Hepatocyte necrosis induced by oxidative stress and IL- $1 \alpha$ release mediate carcinogeninduced compensatory proliferation and liver tumorigenesis. Cancer Cell 14: 156-165.

Sakurai T, Maeda S, Chang L, Karin M. 2006. Loss of hepatic NF- $\kappa$ B activity enhances chemical hepatocarcinogenesis through sustained c-Jun $\mathrm{N}$-terminal kinase 1 activation. Proc Natl Acad Sci 103: 10544-10551.

Senftleben U, Cao Y, Xiao G, Greten FR, Krahn G, Bonizzi G, Chen Y, Hu Y, Fong A, Sun SC, et al. 2001. Activation by IKK $\alpha$ of a second, evolutionary conserved, NF-к B signaling pathway. Science 293: 1495-1499.

Thornburg NJ, Kulwichit W, Edwards RH, Shair KH, Bendt KM, Raab-Traub N. 2006. LMP1 signaling and activation of NF-кB in LMP1 transgenic mice. Oncogene 25: 288-297.

Uren AG, O'Rourke K, Aravind LA, Pisabarro MT, Seshagiri S, Koonin EV, Dixit VM. 2000. Identification of paracaspases and metacaspases: Two ancient families of 


\section{Karin}

caspase-like proteins, one of which plays a key role in MALT lymphoma. Mol Cell 6: 961-967.

Vallabhapurapu S, Matsuzawa A, Zhang W, Tseng PH, Keats JJ, Wang H, Vignali DA, Bergsagel PL, Karin M. 2008. Nonredundant and complementary functions of TRAF2 and TRAF3 in a ubiquitination cascade that activates NIK-dependent alternative NF- $\mathrm{B}$ signaling. Nat Immunol 9: 1364-1370.

Van Antwerp DJ, Martin SJ, Kafri T, Green DR, Verma IM. 1996. Suppression of TNF- $\alpha$-induced apoptosis by NF-кB. Science 274: 787-789.

Wang CY, Mayo MW, Baldwin AS Jr. 1996. TNF- and cancer therapy-induced apoptosis: Potentiation by inhibition of NF-кB. Science 274: 784-787.
Willis TG, Jadayel DM, Du MQ, Peng H, Perry AR, Abdul-Rauf M, Price H, Karran L, Majekodunmi O, Wlodarska I, et al. 1999. Bcl10 is involved in $\mathrm{t}(1 ; 14)$ ( $222 ; \mathrm{q} 32)$ of MALT B cell lymphoma and mutated in multiple tumor types. Cell 96: 35-45.

Wong VW, Yu J, Cheng AS, Wong GL, Chan HY, Chu ES, Ng EK, Chan FK, Sung JJ, Chan HL. 2009. High serum interleukin-6 level predicts future hepatocellular carcinoma development in patients with chronic hepatitis B. Int J Cancer 124: 2766-2770.

Xiao G, Cvijic ME, Fong A, Harhaj EW, Uhlik MT, Waterfield M, Sun SC. 2001. Retroviral oncoprotein Tax induces processing of NF- $\mathrm{\kappa B} 2 / \mathrm{p} 100$ in T cells: Evidence for the involvement of IKK $\alpha$. EMBO J 20: 6805-6815. 


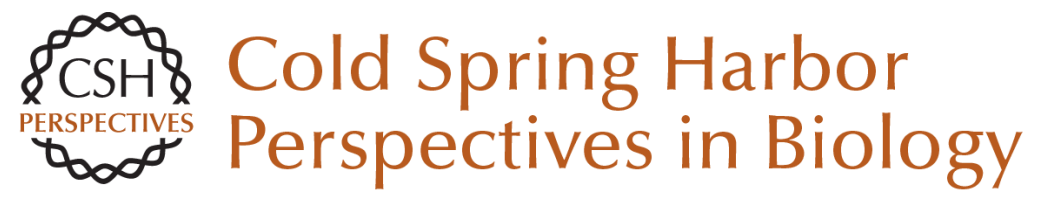

\section{NF- $\kappa B$ as a Critical Link Between Inflammation and Cancer}

Michael Karin

Cold Spring Harb Perspect Biol 2009; doi: 10.1101/cshperspect.a000141 originally published online September 30, 2009

\section{Subject Collection NF-kB}

Use of Forward Genetics to Discover Novel

Regulators of NF- $\mathrm{KB}$ Tao Lu and George R. Stark

Selectivity of the NF-kB Response Ranjan Sen and Stephen T. Smale

NF- $K B$ in the Nervous System

Barbara Kaltschmidt and Christian Kaltschmidt

Signaling to NF- $\kappa B$ : Regulation by Ubiquitination Ingrid E. Wertz and Vishva M. Dixit

Ubiquitination and Degradation of the Inhibitors of NF- KB

Naama Kanarek, Nir London, Ora Schueler-Furman, et al.

A Structural Guide to Proteins of the NF- $\mathrm{KB}$ Signaling Module

Tom Huxford and Gourisankar Ghosh

NF- $\kappa B$ in the Immune Response of Drosophila Charles Hetru and Jules A. Hoffmann

\section{Control of NF-kB-dependent Transcriptional}

Responses by Chromatin Organization Gioacchino Natoli
Oncogenic Activation of NF- $\mathrm{kB}$

Louis M. Staudt

The Regulatory Logic of the NF- $\mathrm{kB}$ Signaling

System Ellen O'Dea and Alexander Hoffmann

Roles of the NF- $k B$ Pathway in Lymphocyte

Development and Function

Steve Gerondakis and Ulrich Siebenlist

The IKK Complex, a Central Regulator of NF- $\kappa B$

Activation Alain Israël

NF- $\kappa B$ in the Nervous System

Barbara Kaltschmidt and Christian Kaltschmidt

The Nuclear Factor NF- $\kappa B$ Pathway in Inflammation

Toby Lawrence

NF- $\mathrm{KB}$ as a Critical Link Between Inflammation and Cancer Michael Karin

Specification of DNA Binding Activity of NF-KB Proteins

Fengyi Wan and Michael J. Lenardo

For additional articles in this collection, see http://cshperspectives.cshlp.org/cgi/collection/

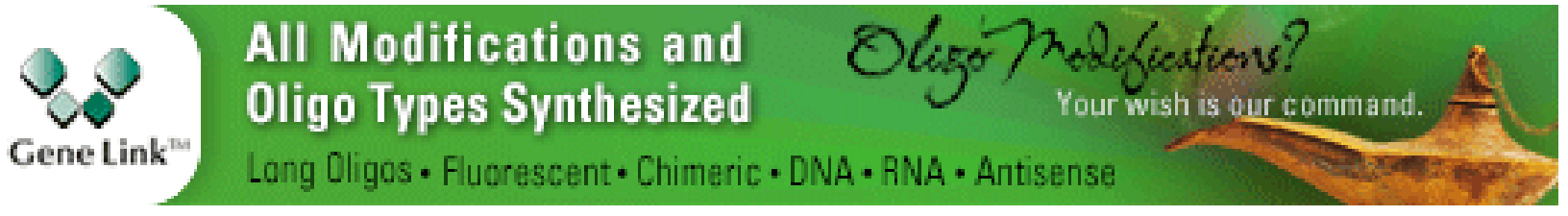

Copyright @ 2009 Cold Spring Harbor Laboratory Press; all rights reserved 